\title{
SEATED VOLLEYBALL: THE INFLUENCE OF MOTOR DEFICIENCY TYPE ON PLAYERS'TACTICAL ROLES
}

\author{
VOLEIBOL SENTADO: INFLUÊNCIA DA DEFICIÊNCIA MOTORA NOS PAPÉIS TÁTICOS DOS JOGADORES
}

VOLEIBOL SENTADO: INFLUENCIA DE LA DISCAPACIDAD MOTORA EN LAS FUNCIONES TÁCTICASDELOS

ARTIGO ORIGINAL

Artículo Original

\section{JUGADORES}

Bruna da Silva Sousa' $\mathbb{1 D}$

(Physiotherapist)

Vera Regina Fernandes da Silva (ID)

Marães ${ }^{2}$

(Physiotherapist)

Marilia Miranda Forte Gomes² (ID (Statistician)

Leonardo Lamas ${ }^{3}$ (D)

(Physical Educational Professional)

1. Universidade de Brasília (UnB),

Master's Degree Program in

Biomedical Engineering, Gama,

DF, Brazil.

2. Universidade de Brasília (UnB),

Master's Degree Program in

Biomedical Engineering, Gama,

DF, Brazil.

3. Universidade de Brasília (UnB),

Faculdade de Educação Física (FEF),

Brasília, DF, Brazil.

\section{Correspondence:}

Bruna da Silva Sousa.

QR 402, Conj. 29, casa 12,

Samambaia Norte, Brasília,

DF, Brazil. 72318-030.

sousabrunadasilva@gmail.com

\begin{abstract}
Introduction: Sitting volleyball is an adapted sport played by players in the seated position, due to impaired mobility or amputations. Court dimensions are adjusted to the players' average height, and during the games, the actions performed are similar to those of traditional volleyball. Objective: To analyze the tactical performance of lower limb amputees and physically disabled athletes during seated volleyball games. Methods: Data were collected from video footage, by a single observer, of twelve games of the Brazilian north-northeast championship 2017. The analysis investigated: i) average length of rallies; ii) frequency of attack actions; iii) game actions by amputation type; iv) outcomes of the actions by amputation type; v) direction and frequency of movements by disability. Results: The average duration was 70 rallies per game, with the minimum disabled athletes performing the highest number of attack actions (43). Transfemoral amputees performed the highest number of blocking actions per game (10.5, in average). Conclusion: Sitting volleyball has characteristics that are determined mainly by the type of disability. Players with minimal disabilities perform more attack actions and have higher performance per action, while amputees perform actions closer to the net, such as blocking and blocking points. The results also suggest that the type of amputation influences the direction of movement. Level of evidence II; Study Prospective.
\end{abstract}

Keywords: Physical disability; Performance; Volleyball; Paralympic athletes.

\section{RESUMO}

Introdução: O voleibol sentado é uma adaptação praticada pelos jogadores em sedestação devido a mobilidade prejudicada ou amputações. As dimensões da quadra são ajustadas à altura média dos jogadorese, durante os jogos, as ações realizadas são semelhantes às do vôlei tradicional. Objetivo: Analisar o desempenho tático de amputados de membros inferiores e deficientes físicos durantejogos de voleibol sentado. Métodos: Os dados foram coletados em 12 jogos do campeonato brasileiro norte-nordeste de 2017 a partir de imagens de vídeo, por um único observador. A análise investigou: i) duração média dos ralis; ii) frequência de ações de ataque; iii) ações de jogo por tipo de amputação; iv) resultados das ações por tipo de amputação; v) direção e frequência de deslocamentos por deficiência. Resultados: A duração média dos ralis foi de 70 ralis por jogo, sendo o deficiente mínimo responsável pela maior frequência de ações de ataque (43), enquanto os amputados transfemorais foram responsáveis pelo maior número de ações de bloqueio por jogo (em média, 10,5). Conclusão: As características do voleibol sentado são determinadas principalmente pelo tipo de deficiência. Jogadores com deficiência mínima são responsáveis pelas ações de ataque e maior desempenho por ação, enquanto os amputados são responsáveis por ações mais próximas da rede, como bloqueio e pontos de bloqueio. Os resultados sugerem ainda que o tipo de amputação influencia a direção do deslocamento. Nível de evidência Il; Estudo Prospectivo.

Descritores: Deficiência física; Desempenho; Voleibol; Atletas paraolímpicos.

\section{RESUMEN}

Introducción: El voleibol sentado es una adaptación practicada por los jugadores en sedestación debido a movilidad reducida o amputaciones. Las dimensiones de la cancha se ajustan a la altura promedio de los jugadores y, durante los juegos, las acciones realizadas son similares a las del voleibol tradicional. Objetivo: Analizar el desempeño táctico de los amputados de miembros inferiores y personas con discapacidades físicas durante los juegos de voleibol sentado. Métodos: Un solo observador recopiló datos en 12 juegos del campeonato brasileño norte-nordeste de 2017 a partir de imágenes de video. El análisis investigó: i) duración promedio de los rallies; ii) frecuencia de las acciones de ataque; iii) acciones del juego por tipo de amputación; iv) resultados de las acciones por tipo de amputación; v) dirección y frecuencia de los desplazamientos por deficiencia. Resultados: La duración promedio de los rallies fue de 70 rallies por juego, y los discapacitados mínimos fueran responsables por la mayor frecuencia de acciones de ataque (43), mientras que los amputados transfemorales fueron responsables por el mayor número de acciones de bloqueo por juego (promedio de 10,5). Conclusión: Las características del voleibol sentado están determinadas principalmente por el tipo de discapacidad. Los jugadores con discapacidades mínimas son responsables por las acciones de ataque 
y un mayor rendimiento por acción, mientras que los amputados son responsables por acciones más cercanas a la red, como el bloqueo y los puntos de bloqueo. Los resultados también sugieren que el tipo de amputación influye en la dirección del desplazamiento. Nivel de Evidencia II; Estudio prospectivo.

Descriptores: Deficiencia física; Rendimiento; Voleibol; Atletas paraolímpicos.

\section{INTRODUCTION}

Seated volleyball is an adapted sport that since the first Paralympic Games, in 1960, has gained practitioners all over the world, including in Brazil. The sport is practiced with all the players seated on a court with 10 meters $\times 6$ meters. Net is 1.15 meter and 1.05-meter height, respectively, for men and women. ${ }^{1,2}$ Each team has six players, with mobility disorders, amputations, or healthy individuals who commit to play according to the rules of the game. ${ }^{1}$

Players classification encompasses a minimum disability or deficiency and other deficiency classes, according to the level of amputation in the lower limbs. The most frequent amputations are: I) hip disarticulation (medial height incision of $1.5 \mathrm{~cm}$ medial to the anterior superior iliac spine), II) transfemoral amputation (cut between knee disarticulation and hip), III) transtibial amputation (disarticulation of the ankle and preservation of the knee joint) 1,3 Another class of deficiencies are permanent or irreversible pathologies in terms of muscle power, tone and muscle coordination. Regarding the minimum deficiencies, mobility is reduced due to injuries in ligaments or tendons, affecting mainly knees and ankles. ${ }^{4}$

A main trend in the literature about seated volleyball is to approach the game through the perspective of basic teaching guidelines, ${ }^{5}$ rules of the game ${ }^{6,7}$ and analysis of the main technical demands of the players., ${ }^{8,9}$ Only a few studies aimed to approach performance analysis from a tactical perspective. ${ }^{7,8,10}$ In one of them, ${ }_{1}^{8}$ the authors investigated the proportions of points, errors and adversary errors in seated volleyball games. Findings indicated a predominance of points. Additionally, the influence of positioning in the serve success has been also investigated. ${ }^{10}$ The study evidenced that players usually choose the position that favor the hip push to perform the service movement. Finally, Haiachi et al. ${ }^{7}$ investigated the influence of the serve and the attack in the team success. Results indicated that serve is determinant and attack can also present a major contribution, in some cases. Although these studies approached some general tactical features of seated volleyball, it is still missing investigations focused on the details of the players'tactical roles. In this sense, game analysis centered in the players' actions seems to be an efficient approach to provide feedback for improving team performance ${ }^{11-13}$ and the overall knowledge about the game. Therefore, the goal of the present study was to investigate the relation between players' deficiency and their tactical roles in seated volleyball.

\section{MATERIALS AND METHODS}

The sample consisted of six teams participating in the Brazilian North-Northeast Seated Volleyball Championship - 2017. Fifteen games were analyzed, with 33 sets and 837 rallies. Video footage obtained from the Brazilian Volleyball Confederation (CBVD) was used to collect the dataset for analysis. The present study was approved by the Ethics Committee of the Faculty of Health Sciences (FS), with CAAE 38386714.8.0000.0030.

For determining tactical performance and its interaction with deficiency type, the following variables were annotated for every player: I) type of deficiency, II) game actions performed, III) outcome of game actions, IV) direction and frequency of displacement.

Type of deficiency was categorized as follows: I) Right Transfemoral (RTF), ii) Left Transfemoral (LTF), III) Right Transtibial (RTT), iv) Left Transtibial $(\mathrm{LT}), \mathrm{V})$ Right Hip Amputation (RHA), VI) Left Hip Amputation (LHA), VII) Transtibial Bilateral Amputation (TBA), VIII) Bilateral Transfemoral Amputation (BTA), IX) Transtibial and Transfemoral Amputation (TTA), x) Bilateral Hip and Transfemoral Amputation (BHTA), XI) Hip and Transtibial Amputation (HTA), XII) Bilateral Hip Amputation (BHA), XIII) Minimal Deficit (MD).

Game actions were divided in two types: point actions and regular actions. Point actions: I) ace point (generated by correct serves), II) wrong pass, leading to a point of the opposing team, III) defensive turnover (wrong action during opponent's defense), IV) lock point, V) point from an attack, VI) wrong attack (opponents' serve errors). Regular actions: I) pass, II) touch, III) block, IV) reception, V) serve, VI) defense and VII) attack.

Game actions' outcomes were categorized as: I) continuity (possession maintenance), II) pointless attack (attack action received by the other team), III) point.

Direction of displacements was categorized as: front, back, right, left and none.

Based on these annotations, we analyzed: I) average length of rallies; II) frequency of attack actions; III) game actions per amputation type; IV) direction and frequency of displacements per deficiency; $V$ ) success rate of actions per amputation (outcomes assessment); $\mathrm{VI}$ ) lineups that resulted in points for the team.

\section{Statistical analysis}

Descriptive statistics and Pearson correlations were calculated ( $p$ value $\leq 0,05)$. All data were analyzed in the Statistical Package for Social Sciences (SPSS) software.

\section{RESULTS}

We analyzed 837 rallies, during 12 games, with an average of 70 rallies per game, distributed in 33 sets, with the participation of 43 players. Table 1 displays the frequencies of game actions per rally, for each amputation type.

Table 1. Game actions per rally for each amputation type. Frequencies normalized by the number of rallies played by each player.

\begin{tabular}{|c|c|c|c|c|c|c|}
\hline Game actions & $\begin{array}{c}\text { Bi-amp } \\
\text { transfemoral }\end{array}$ & $\begin{array}{c}\text { Bi-amp hip and } \\
\text { transtibial }\end{array}$ & Transfemoral left & Transfemoral right & Transtibial left & Deficient minimum \\
\hline Pass & 0.25 & 1.00 & 0.00 & 0.00 & 0.01 & 0.00 \\
\hline Touch & 0.75 & 0.00 & 0.05 & 0.06 & 0.09 & 0.01 \\
\hline Block & 0.00 & 1.00 & 0.27 & 0.31 & 0.48 & 0.09 \\
\hline Reception & 0.00 & 0.00 & 0.57 & 0.66 & 1.02 & 0.20 \\
\hline Serve & 0.25 & 0.00 & 0.07 & 0.09 & 0.13 & 0.02 \\
\hline Defense & 0.25 & 0.00 & 0.10 & 0.12 & 0.18 & 0.03 \\
\hline Attack & 0.75 & 0.00 & 0.07 & 0.09 & 0.13 & 0.02 \\
\hline
\end{tabular}


In Figure 1, it is presented the absolute frequencies of outcomes for each amputation type. For visualization purposes, successful actions' outcomes are positive on the $x$-axis, while unsuccessful actions' outcomes are represented as negative.

The vector of displacement's direction per amputation $\rightarrow$ ) is presented in Figure 2. There was a strong correlation between the amputation type and the displacement direction $(r=0.90 ; p<0.05)$. In Figure 2, data inside parentheses represent proportions of: I) the vector in relation to the other three vectors of the same amputation; II) the same vector direction for all amputation types. Data was standardized by the number of rallies disputed by each player.

Game actions and outcomes observed in the games analyzed are displayed in Figure 3. Classes of actions were organized for an accurate analysis of outcome tendencies per amputation.

Figure 4 displays lineups with greatest performances for the three possible scoring outcomes: I) points - all points obtained, except by those derived from an attack; II) attacks with point - points obtained after an attack action; III) points from block - point obtained after a block.

\section{DISCUSSION}

The present study presented original findings about the tactics of the seated volleyball game in regards to the influence of the disability in the game actions and respective outcomes. Minimally disabled players were responsible for the largest number of actions per rally and rallies' outcomes, mainly, attack actions. Complementary, transfemoral amputees were more responsible for blocking actions. The displacements performed by amputees were performed in greater proportion to the opposite direction of the player's residual stump, whereas bi-amputated individuals did not present displacements during the rallies. Results also evidenced a relationship between the actions performed and the lineup composition. Lineups with a greater number of amputees were those that achieved higher error frequencies or enabled more points scored by the opposing team. ${ }^{14,15,16}$

In the present study, we found an average of 70 rallies per game, along the 33 sets analyzed. This result differs from other that found an average of 43 rallies per game, in 24 sets, ${ }^{7}$ suggesting the competition level may impact the duration of the rally. Interestingly, in seated volleyball the duration of the rally may be influenced by distinct factors than those in volleyball. ${ }^{17,18}$ Previous studies investigated the relation between rallies' duration and the outcome in the highest performance levels of volleyball. 19,20 The attack in the side-out phase (i.e. serving team) imposes initial difficulties to the other team to sustain the bal and organize their offense (i.e. the counter-attack), leading to a general short duration. ${ }^{21}$ In the cases of longer rallies, initial advantage of the serving team was lost. ${ }^{22}$ In seated volleyball, our results indicated that neither the serve not the attack presented distinguished performances in terms of points obtained (Figure 3). Since the positive outcome obtained through these actions in volleyball may be related to the height of the reaching point of the ball in the attack, enabling a more vertical trajectory of the ball towards the opponent court, in seated volleyball game dynamics may be different as evidenced by the data. In seated volleyball, although a higher attack may favor a team's performance,

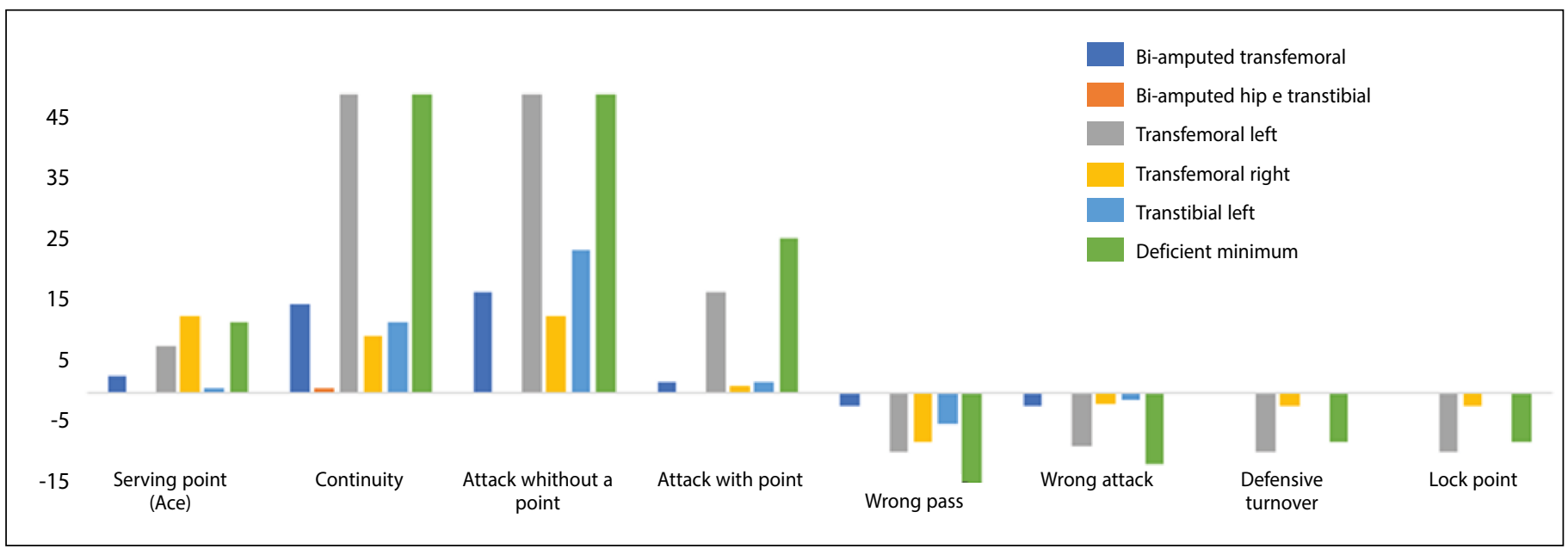

Figure 1. Absolute frequencies of game actions' outcomes per amputation type.

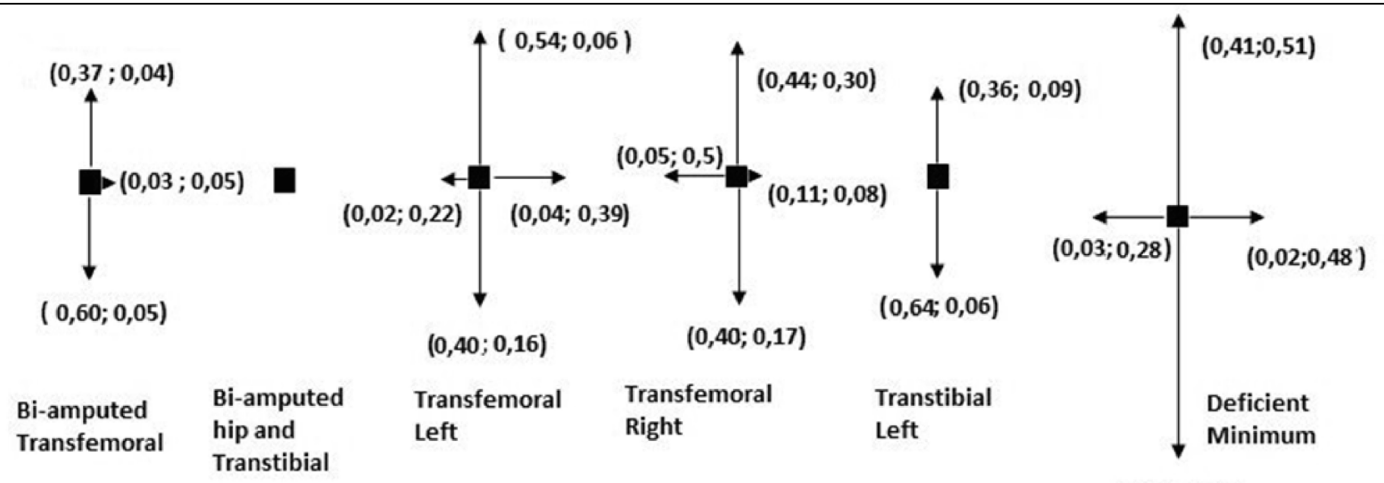

$(0,54 ; 0,56)$

Displacement direction $\rightarrow$ 


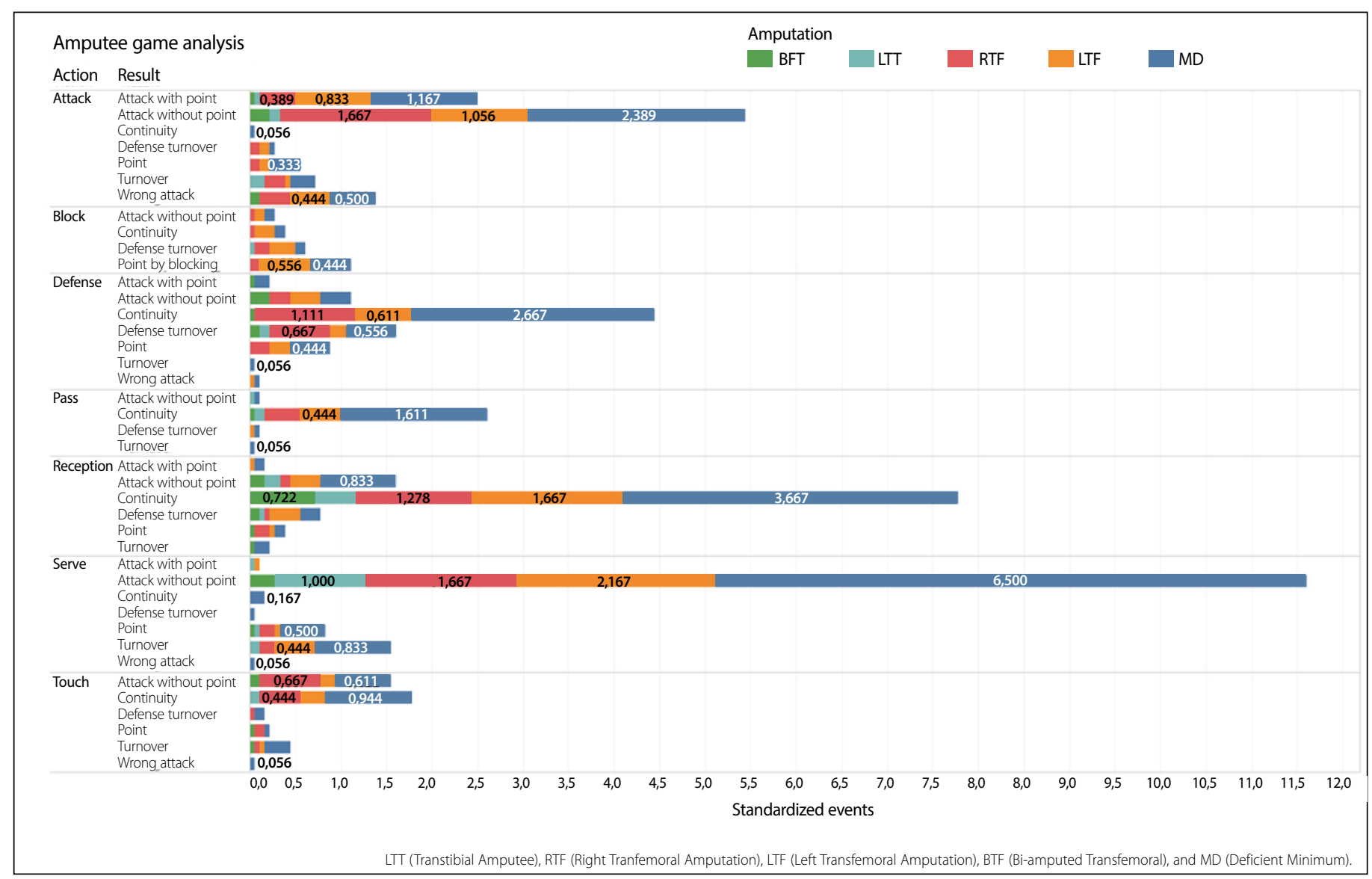

Figure 3. Game actions and related outcomes per amputation type.

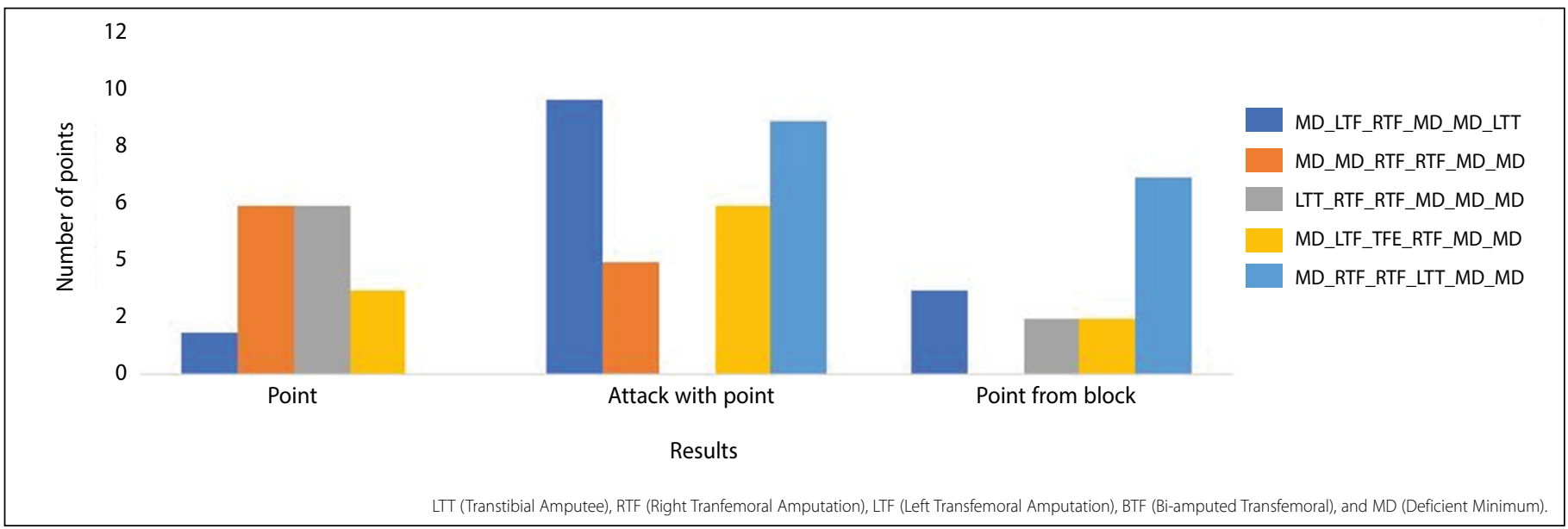

Figure 4. Lineups and respective frequency of points made.

its influence on the end of a rally may be balanced by the opponents' ability to displace and position to protect the field. Possibly, the better the performance level of teams the higher their competence to avoid the ball to touch the floor. Future studies may further investigate these singularities of seated volleyball, as a net sport ${ }^{23}$ with a possible great balance between offensive and defensive efficiencies.

The previous reasoning gains additional complexity because seated volleyball encompasses players with distinct disabilities. The heterogeneity of players' motor abilities impacts their displacements (Figure 2) and, consequently, the game dynamics and the efficiency of a team to attack and defend depending on the players on court in each moment. The minimum deficiency group represented the only set of players with ability to perform displacements in the four directions considered (Figure 2). Players with transfemoral amputations have demonstrated the ability to move to the opposite side of their amputations, possibly performing the movement with the opposite leg. Besides that, actions such as pull and block require forward and backward movements, possibly influencing transfemoral amputees to perform larger shifts to these directions. Transfemoral bi-amputee players were also able to displace back and forward and only hip and transtibial bi-amputee presented absence of displacement. Except by the hip and transtibial bi-amputee, all other players' profiles presented at least the back and forward displacement. The relation between the amputation type and the displacement profile suggests tactical trends in the game that might be considered to optimize a team's performance. ${ }^{17}$

In complement to the displacements' profile, our analysis indicated that the minimum disabled players were responsible for the greater number of actions (Figure 3), especially the service, reception, action 
and blocking. Players with more severe disabilities presented lower frequencies of these actions. It may be the case that players with minimal deficiency, due to their partially preserved bone, muscle and ligamentous areas, present better requirements for movement and execution of the game actions, compared to lower limb amputees. ${ }^{3,17}$

The characterization of players' displacement abilities, associated with the main displacement trends per amputation type may be helpful for coaches to define playing strategies. It is worth noting that withdrawal was more frequent in the minimal disabled and transfemoral amputees, possibly because of fatigue, given the high displacement demands of these players. This may impose special requirements in terms of the physical conditioning of these players.

In terms of actions outcomes, it has been evidenced in the past that the low frequency of errors is a determinant factor for the team success. ${ }^{18}$ In the present study, previous evidence about the relevance of errors was complemented by a result indicating the transfemoral biamputees and transfemoral amputees were responsible for the higher frequencies of errors in comparison to the number of points earned by them. This may helpful to a coach reflects about the performance trade-offs of his team players.

The subjects of players' displacement tendencies and the tactical trends of each player profile converge to the issue of the team lineup. Combining players on court in ideal lineups is a challenging task, which has been frequently investigated. ${ }^{24}$ As previously indicated in other studies changes in the lineup cause modifications in the offensive pattern of a team. ${ }^{18,19}$ In the present study, one of the line-ups with highest efficiencies was that with the greatest number of minimum disabled players, while the lineup that presented the greatest frequency of errors was that with most amputee players. In addition, the lineup has a direct impact on attack actions, which are those with greater chances of error. ${ }^{11}$ Hence, In the players' lineup composition, coaches may define players in their rotations considering the trade-off between their scoring and error probabilities to increase the chances of positive outcomes.

\section{CONCLUSION}

Sitting volleyball tactics represent a challenging research field with several subtleties derived from the interaction between the disability of players and their tactical tendencies, besides inter-individual abilities. Methodological frameworks applied to volleyball and even to other sports may be progressively adapted to sitting volleyball to assess its particularities and increase the knowledge that may support the practice of this sport.

Future works may focus, for instance, in the relevance of the distinct game complexes to the team performance in order to increase the understanding of the game dynamics.

\section{ACKNOWLEDGMENT}

We thank the Association of Special Physical Education Training Center -CETEFE, the teams of the 2017 north-east sitting volleyball championship, and the Coordination for the improvement of personnel of higher level (CAPES) for the financial assistance during the master's degree.

All authors declare no potential conflict of interest related to this article

AUTHORS' CONTRIBUTIONS: Each author made significant individual contributions to this manuscript. BSS: writing, revision, analysis of the data and statistical analysis; VRFSM: analysis of the data and writing; MMFG: statistical analysis and revision; LL: writing, statistical analysis, revision, intellectual concept and preparation of the research project.

\section{REFERENCES}

1. Mello MT, Winckler C. Paralympic Sport, São Paulo: Atheneu, 2012.

2. Pastre CM. Physiotherapy and transtibial amputation. Arq Cienc Saúde. 2005 [acesso em 2018 set 10];12(2):120-4. Disponivel em: http://repositorio-racs.famerp.br/racs_ol/Nol-12-2/11.pdf

3. Carvalho JA. Lower limb amputations: in search of full rehabilitation. 2nd ed. São Paulo: Manole; 2003.

4. Brazilian Confederation of Volleyball. História. 1nd ed. São Paulo: Brazilian Confederation of Volleyball. 2016 [acesso em 2018 set 10]. Disponível em: http://2015.cbv.com.br/cbv/institucional/historia.

5. Gomes NR, Souza CJ. Análise Biomecânica dos movimentos do voleibol sentado: um estudo eletromiográfico sobre o deslocamento. XVIII CONBRACE and V CONICE, Brazil. 2013 [acesso em 2018 out 12]. Disponível em: http://congressos.cbce.org.br/index.php/conbrace2013/5conice/paper/viewFile/5538/2879.

6. Carvalho CL, Gorla Jl, Araújo PF. Sitting volleyball: the knowledge to initiation of practice. Conexões. 2013 [acesso em 2018 set 10];11(2):97-126. Disponível em: https://doi.org/10.20396/conex.v1 1i2.8637619.

7. Haiachi MC, Oliveira BR, Almeida MB, Santos TM. Performance indicators in sitting volleyball. Rev Educ Fis / UEM. 2014 [acesso em 2018 out 12];25(3):335-43. Disponível em: http://www.scielo.br/scielo. php?script=sci_arttext\&pid=S1983-30832014000300335.

8. Borges, A.C., Oliveira, L.D., Neto, A.A., Batista, G.R., \& Souto, E.C.. Desempenho Técnico em Equipes de Voleibol Sentado Masculino. J Health Sci. 2016 [acesso em 2018 set 17];18(1):28-31. Disponível em: http://dx.doi.org/10.17921/2447-8938.2016v18n1p28-31

9. Souto EC, Oliveira LS, Meira Neto A, Greguol M. Scientific authenticity of an agility test for sitting volleyball. Motricidade. 2015 [acesso em 2018 out 14];11(4):82-91. Disponível em: http://dx.doi. org/10.6063/motricidade.4061.

10. Meira TB, Bastos FC, Böhme MTS. Análise da estrutura organizacional do esporte de rendimento no Brasil: um estudo preliminar. Rev Bras Educ Fís. Esporte. 2012 [acesso em 2018 set 17];26(2):251-62. Disponível em: http://dx.doi.org/10.1590/S1807-55092012000200008

11. Drikos S, Kountouris P, Laios A, Laios, Y. Correlates of team performance in volleyball. Inter J Perf Analysis Sport. 2009 [acesso em 2018 out 14];9(2):149-56. Disponível em: https://doi.org/10.1080/24748668.2009.11868472.

12. Porath M, Nascimento JV, Milistetd M, Collet C, Salles, WN, Quinaud RT. Nível de desempenho técnico-tático e experiência esportiva dos atletas de voleibol das categorias de formação. Rev Edu Fís / UEM. 2012 [acesso em 2018 out 17];23(4):565-74. Disponível em: http://www.scielo.br/pdf/rbce/v38n1/0101-3289-rbce-38-01-0084.pdf.
13. Lamas L, Barrera J, Otranto G, Ugrinowitsch C. Invasion team sports: strategy and match modeling Inter J Perf Analysis Sport. 2017 [acesso em 2018 set 18];14(1):307-29. Disponível em: https://doi. org/10.1080/24748668.2014.11868723.

14. Wiśniowska M, Tasiemski T, Bauerfeind J. Athletic identity assessment in disabled sitting volleyball players. Physiotherapy/Fizjoterapia. 2012;20(1):10-9.

15. Sheppard JM, Young WB. Agility literature review: Classifications, training and testing. J Sports Sci. 2006 [acesso em set 10];24(9):919-32. Disponível em https://doi.org/10.1080/02640410500457109.

16. Campos FA, Pellegrinotti IL, Pasquarelli BN, Ozaki EH, Stanganélli LC. Análise da vantagem de jogar em casa no voleibol feminino brasileiro. Rev Bras Ci Mov. 2015;23(1):40-7. Disponível em https:// doi.org/10.18511/0103-1716/rbcm.v23n1p40-47

17. Ackland TR, Elliott BC, Blomfield J. Anatomia e biomecânica aplicadas no esporte. 2nd ed. São Paulo: Manole; 2011.

18. Guerra AA.Estudo da organização ofensiva em voleibol - Estudo aplicado em equipas de elite mundial. [Tesis Doctoral]. FADEUP. Universidade do Porto; 2007. [acesso em 2018 out 18];1-183. Disponível em: https://repositorio-aberto.up.pt/bitstream/10216/14488/2/38322.

19. João PV, Mesquita I, Sampaio J, Moutinho C. Análise comparativa entre o jogador libero e os recebedore prioritários na organização ofensiva, a partir da recepção ao serviço, em voleibol. Rev Port Cien Desp. 2006 [acesso em 2018 out 18];6(3):318-28. Disponível em: http://www.scielo.mec.pt/scielo. php?script=sci_arttext\&pid=\$1645-05232006000300007\&lng=pt.

20. Sánchez-Moreno J, Marcelino R, Mesquita I, Ureña A. Analysis of the rally length as a critical incidente of the game in elite male volleyball. Inter J Perf Analysis Sport. 2015;15 (2): 620-31.

21. Marcelino R, Cesar B, Afonso J, Mesquita I. Attack-tempo and Attack-type as predictors of attack point from opposite players in volleyball. Inter J Perf Analysis Sports. 2009.

22. Peña J, Rodríguez-Guerra J, Buscà B, Serra N. Which skills and factors better predict winning and losing in high-level men's volleyball?. J Strength Cond Res. 2013;27(9):2487-93.

23. Vinué G, Epifanio I. Archetypoid analysis for sports analytics. Data Min Knowl Disc. 2017;31(6):1643-77. 24. Rangel W, Ugrinowitsch C, Lamas, L. Basketball players'versatility: assessing the diversity of tactical roles. Inter J Sports Sci Coaching. 2019;14(4):552-61. 